\title{
A Review on the Quality of Palm Oil (Elaeis guineensis) Produced Locally in Imo State, Nigeria
}

\section{Enyoh Christian Ebere ${ }^{1 *}$, Verla Andrew Wirnkor ${ }^{1}$, Enyoh Emmanuel Chinedu ${ }^{2}$, Verla Evelyn $\mathrm{Ngozi}^{3}$}

\author{
${ }^{1}$ Group Research in Analytical Chemistry, Environment and Climate Change, Department of \\ Chemistry, Imo State University, Owerri, Imo State, Nigeria
}

${ }^{2}$ Quality Assurance Department, International Distillers Limited, Ota, Ogun State, Nigeria

${ }^{3}$ Department of Environmental Technology, School of Environmental Technology Federal University of Technology, Owerri, Imo State Nigeria.

${ }^{*}$ cenyoh@gmail.com

Keyword: Health risk, Microorganism, Processing, Small scale, Storage, Traditional methods.

\begin{abstract}
Over $70 \%$ inhabitants of Imo state pend on palm oil for their cooking, frying etc. The study reviews available data on palm oil quality produced locally in Imo state with a view of providing up-to-date information and identify research gaps that could have health consequences on consumers. Peer reviewed scientific articles were reviewed and a meta-analysis of four different scientific research databases, PubMed, Web of Science, Google Scholar and Directory for OpenAccess Journals was conducted. The result showed that palm oil produced locally in Imo state has average of $\mathrm{pH}(4.73)$, acid value $(28.3 \mathrm{mg} / \mathrm{KOH})$, FFA $(14.15 \mathrm{mg} / \mathrm{KOH})$, smoke point $\left(115^{\circ} \mathrm{C}\right)$, iodine value (1.68 wijj's), saponification value $(197.07 \mathrm{mgKOH} / \mathrm{g})$, ester value (168.77), moisture content $(0.44 \%)$, density $(0.89 \mathrm{~g} / \mathrm{ml})$, SG $(0.91)$, peroxide value $(17.75 \mathrm{mEq} . / \mathrm{kg})$, refractive index $\left(1.46{ }^{\circ} \mathrm{Bx}\right)$ and viscocity $(60.04 \mathrm{cps})$. Overall palm oil is highly degraded and of poor quality since major quality indicators are not within Nigerian Industrial Standard and Standard Organization of Nigeria. Also, there is a dearth of information/data available on quality of palm oil produced locally in Imo state especially on its microbial status. Food scientist should look in that direction to enhance proper understanding of the quality of palm oil.
\end{abstract}

\section{Introduction}

Palm oil is an edible oil, reddish in colour derived from the fruits of the oil palm Elaeis guineensis, which is indigenous in West Africa [1-3]. The oil palm tree is a perennial tree crop, which produces the highest quantity of oil when compared to other oil producing plants [4-5]. The crop is unique in that it produces two types of oil. The fleshy mesocarp produces palm oil, which is used mainly for its edible properties and the kernel produces palm kernel oil, which has wide application in the oleochemical industry [5-6]. Palm oil consumption in 2015 was estimated at 35\% globally [7] making it the highest consumed vegetable oil.

Like most vegetable oils, palm oil is mainly composed of triglycerides or triacylglycerols which represent $95 \%$ of the total weight constituents [8-9]. It also contains minor compounds such as diacylglycerol, mono glycerol and free fatty acids (FFA) issued from the biosynthesis and / or hydrolysis of triacylglycerols, sterol, tocopherol, pigments and metal ions are also represented [10]. The majority of fatty acids are palmitic acid followed by oleic acid [11-13].

The benefits of palm oil are numerous and at the same time it present health implications from use of poor palm oil. The janus behavior of palm oil is majorly due to its chemistry. Certain properties make it deteriorate faster and so could constitute a health problem when consumed. Palm oil has been used in food preparation for over 5,000 years [14]. The nutritional and health implications have been reviewed and well documented [14-15]. Palm oil has good resistance to oxidative deterioration and its better ability to withstand high temperatures has made it so useful in frying than most alternative oils [16-17]. In addition, it is rich in antioxidant such carotenoids, tocopherols and tocotrienol which when consumed enhance immune function by a variety of 
mechanisms, and can improve cardiovascular health [14]. Carotenoids also play an important potential role by acting as biological antioxidants, protecting cells and tissues from the damaging effect of free radicals through pollutants exposure to cigarette smoke, industrial pollution, stress, unbalance diets, pesticide and insecticide residues in food and water, and many other negative environmental influences [18]. Degenerate diseases such as heart disease and cancer, as well as general ageing are associated with buildup of free radicals in the body. These natural antioxidants act as buffers against free radicals and are believed to play a protective role in cellular ageing, atherosclerosis, cancer, arthritis, and Alzheimer's disease [19]. Other additional benefit is their use in cosmetics [20-21]. They have been blended into mayonnaise and salad oil [22] and have been used so well in soap production.

The aim of this study is to review the available information on the quality of palm oil produced locally in Imo state Nigeria. It is believed that more than $70 \%$ of palm oil users in Imo state uses locally produced palm oil for their domestic activities such as cooking, frying etc. This study is significant as it's bringing into limelight the status of palm oil produced locally in terms of quality. The study also provides baseline information for further research on quality of palm oil produced locally in Imo state.

\section{Sources of Data}

The data/information was sourced from materials such as journals articles and conference/workshop/seminar papers and statistical bulletins. PubMed, Web of Science, Google Scholar and directory for open-access journals (DOAJ) were four scientific databases used to search for related articles using the keywords: palm oil, Imo state, quality (conducted in June 2018) produced limited (numbering 2) citations particular to Imo state while in total number of 74 papers was used in this review. Over $90 \%$ of literatures reviewed were obtained from backdoor searches through references confirming the scarcity of information on the subject matter.

\section{Study Area: Imo State, Nigeria}

The state lies in the South East of Nigeria. The state has 27 local government areas with its capital as Owerri which is also the largest city in the state. Its other major cities are Orlu and Okigwe. Imo occupies the area between the lower River Niger and the upper and middle Imo River. The state lies within latitudes $4^{\circ} 45^{\prime} \mathrm{N}$ and $7^{\circ} 15^{\prime} \mathrm{N}$, and longitude $6^{\circ} 50^{\prime} \mathrm{E}$ and $7^{\circ} 25^{\prime} \mathrm{E}$ with an area of around 5,100 sq km [23]. There is atleast one local palm oil processing unit in each of the 27 local governments (Fig. 1). Example of such unit is Adapalm in Ohjai Egbema, while most others are not with name. 


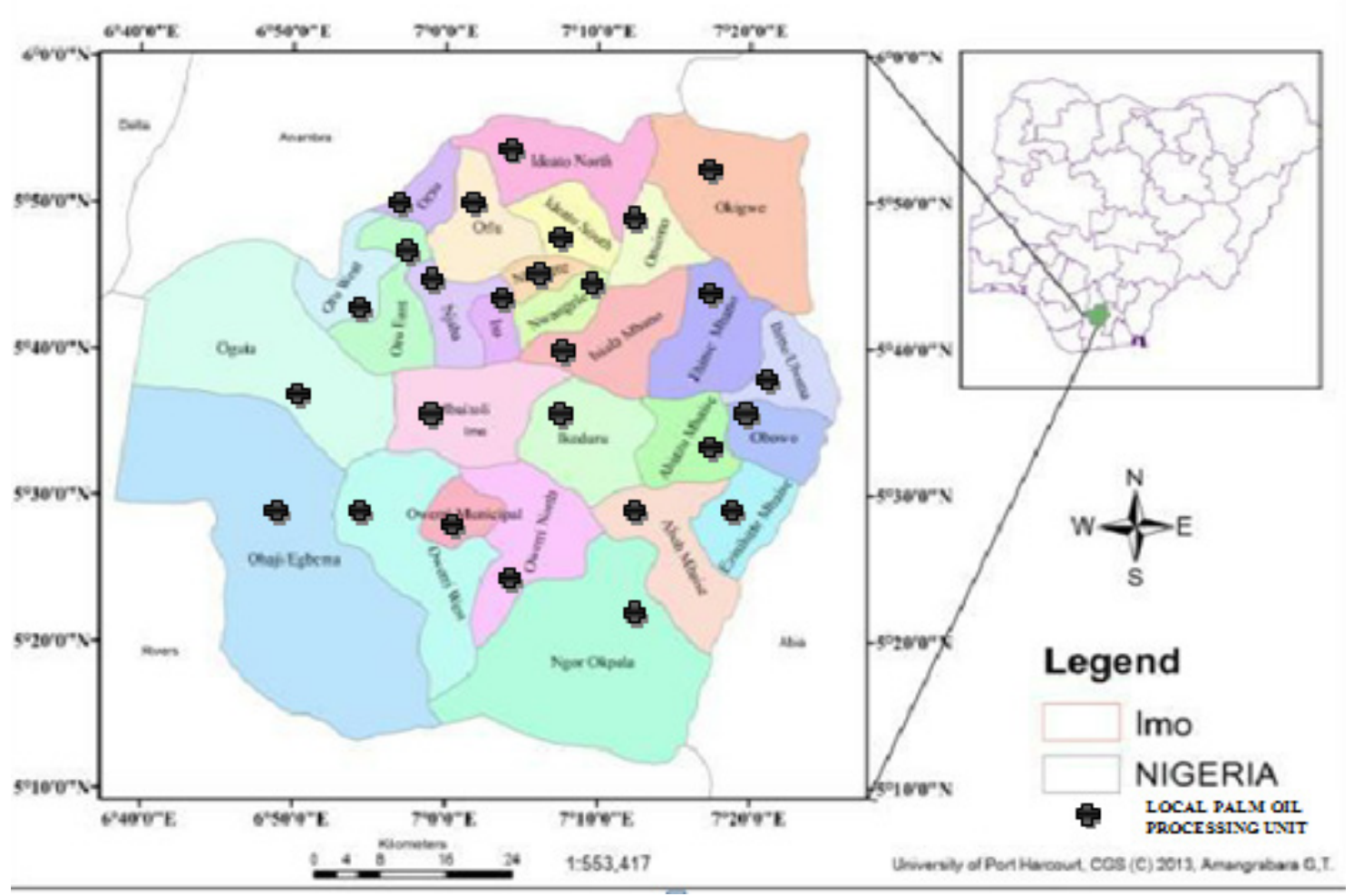

Figure 1. Map of Imo state showing local palm of processing unit (Reprinted and edited from [24])

The chief occupation of the local people is farming with a total of 303,333 farm families in agricultural production of palm oil in the state [25]. These over-farming coupled with high population densities, has greatly degraded soils in the state [26]. The major cash crops grown in the states include oil palm, raffia palm, rice, groundnut, melon, cotton, cocoa, rubber, etc. Consumable crops such as yam, cassava, cocoyam and maize are also produced in large quantities [26].

\section{Palm Oil Production in Imo State}

Palm oil is the main vegetable oil produced in Nigeria and the production is characterized by low yields from traditional methods. Nigeria which was the world leading producer and exporter of palm oil in 1960's has lost its position to Indonesia and Malaysia 45\% and 39\% of the world production in 2010 [27] and now fifth largest producer after Thailand and Colombia [28]. In 2010, Nigeria production accounts for $55 \%$ of the African output. Imports represent $23 \%$ of the total domestic supply (2005-2010) and a 35\% import tariff was applied [29]. Its output indeed represented only $3 \%$ of the world production in 2010 [27]. Palm oil production accounted for $1.5 \%$ of the national agricultural GDP in 2006 [30].

Palm trees grow up in wet rain forests and in savannah, which means that palm oil are produced mainly in the South east such as Imo state. PIND [31] explains that 9 states situated in the Niger Delta including Imo state account for $57 \%$ of the national palm oil production. In Imo state, the production of palm oil is mostly based on semi-natural groves, which have an estimated area of 106,690 hectares [32]. The medium and smallholder plantations and the large estate plantations represent a very small share of the production system [31] with estimated area of 67,690 hectares and 3,410 hectares respectively [32]. As at 2009, 150-200,000 Metric tonnes of palm oil are produced in Imo state $[29,33]$.

The production in Imo is comparable with Abia state and Rivers state, while lower to productions in Akwa Ibom and Cross river ( $>250,000$ Metric tonnes) and higher than Ondo, Edo, Delta, Bayelsa states respectively with productions ranging from 0 to 150,000 Metric tonnes of palm oil. However, Imo has a potential to increase its production through the application of improved processing methods and better marketing [34]. 


\section{Methods for Palm Oil Production in Imo State}

Processing of oil palm fruit is the process by which palm fruits is processed into palm oil through sterilization, trenching or stripping, milling and digestion, pressing and clarification [35]. The main products of the oil palm industry are crude palm oil (CPO) and palm kernel (PK), which yields another type of oil known as palm kernel oil (PKO), and residue known as palm kernel cake (PKC) [36]. Two broad methods of palm oil production have been observed [37]; thus the traditional methods normally referred to as "low" technology and the mechanized process. The mechanized processing involved basically the same principle as the present industrial method, the difference being the equipment and technology employed in addition to the quality of each method.

The characteristics of a finished product, in most cases, depend on the processing techniques applied; these processes are also subject to technical and cost limitations. However, in Imo state most production techniques are done traditionally. Although, the traditional processes is also now undergoing changes; mechanization being superimposed on this area of processing; the implications and ramifications are by no means simple. These mechanized processes are mostly used when processing palm kernel. It was reported that $83 \%$ of palm kernel processors used mechanized technique while $17 \%$ used manual method in Imo state while cracking palm kernel [38]. Also, 45\% of the processors use machines while $30 \%, 15 \%$, and $10 \%$ of the processors use manual, traditional and solvent methods respectively in extracting oil from the palm kernel in Imo state [38]. The simple production technique for palm oil production locally in Imo state was revealed [4] and the flow chart of production is presented in Fig. 2.

$\underline{\text { Some sources of contaminants }}$

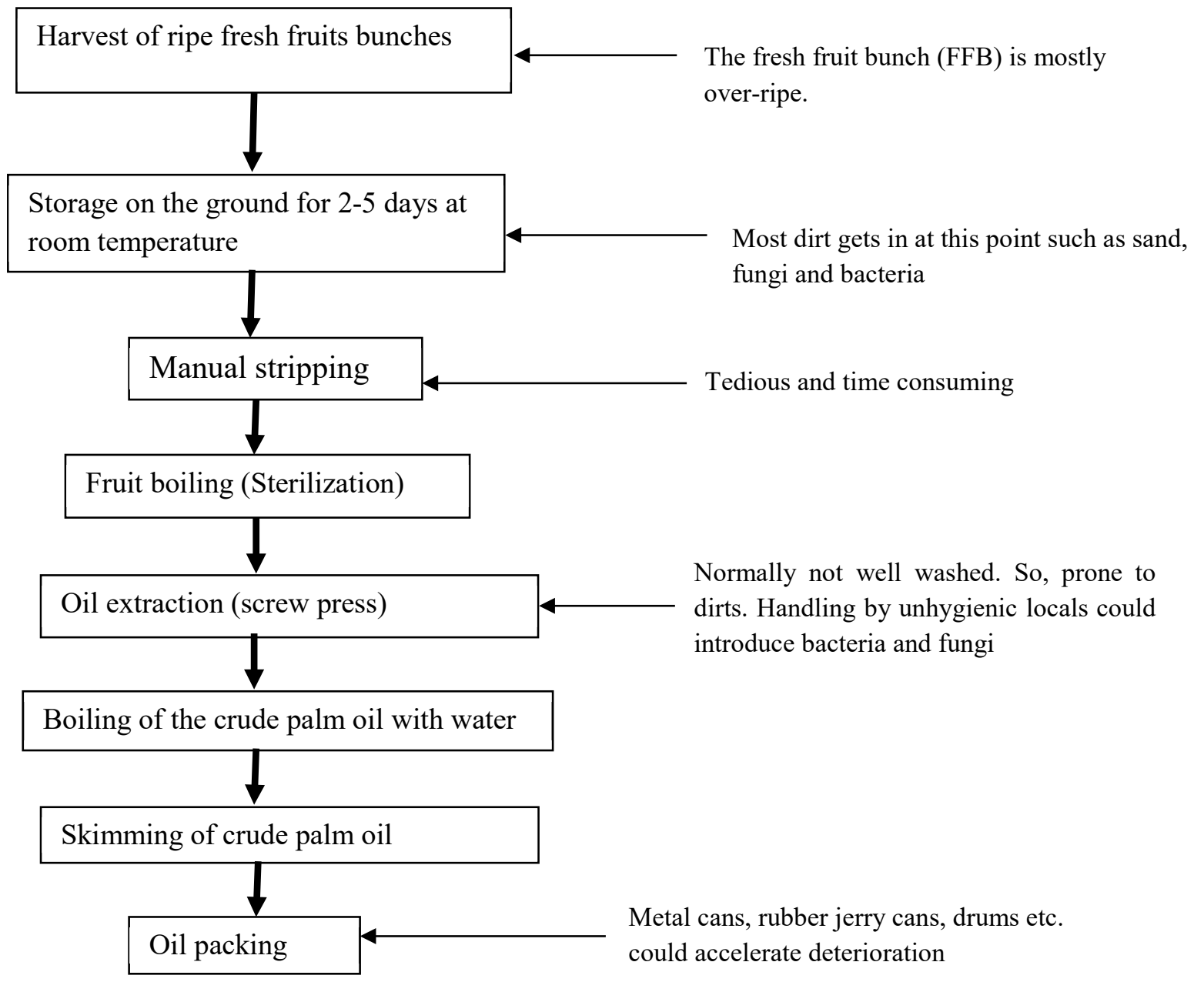

Figure 2. A flowchart for palm oil production in Imo state and possible contamination sources during production 
Enyoh and coworkers [4] stated that "ripe palm fruits bunches were harvested, stored on the ground for 2-5 days at room temperature before sterilization of the palm fruits was carried out by boiling and then the oil was extracted by screw pressing. Thereafter, the extracted crude palm oil was boiled with water and then skimmed for proper clarification of the oil before drying by boiling and finally, packaging in bottles".

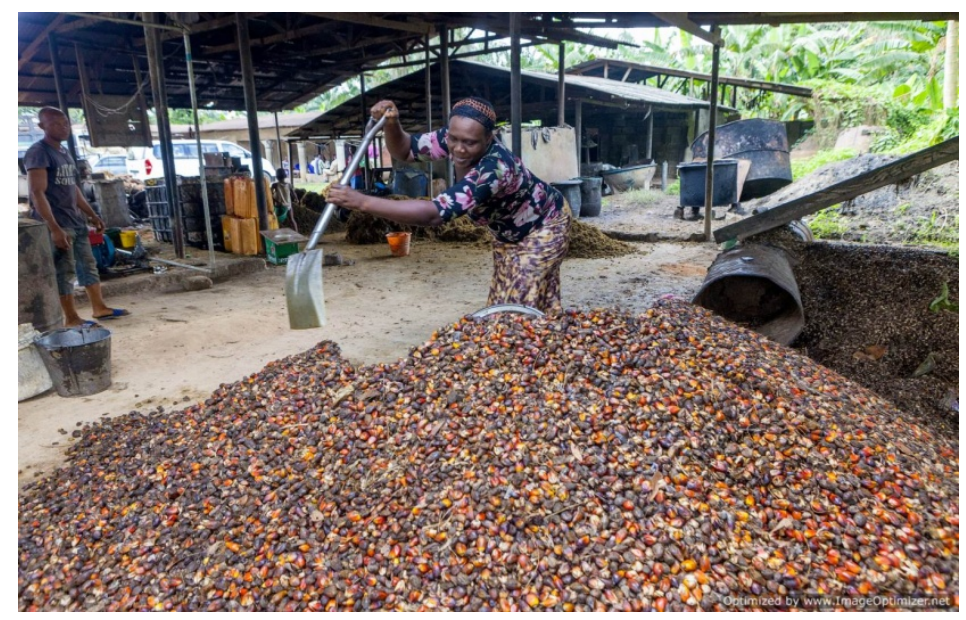

Figure 3. Photograph of a typical local palm oil production unit in Imo state [39].

The photograph (Fig. 3) is showing a woman packing the manually stripped fresh fruit bunch (FFB) for boiling using a shovel. Also, the environment is unclean and could contaminate the whole production processes. However, most palm oil processors in Imo are considered small scale due to low output of palm oil per hour. According to Ataga [40] and FAO [41], processing units handling up to 2 tonnes of fresh fruit bunches (FFB) per hour are considered to be small-scale. The traditional method of processing palm oil is more prevalent among small scale processors and these small scale processors are responsible for the bulk of palm oil processed in Nigeria [34].

The traditional method for oil palm processing is tedious, laborious and time consuming especially for rural women [42]. According to Nwaleiji and Ojike [43], that the success or failure of a processing depends largely upon how labour and other associated resources are efficiently used. Therefore, in order to versatile palm oil production in Imo state, the use current techniques such as biomodification (use of lipase for modifying palm oil and its fractions by interesterification), bioconversion (the use of enzymes and microbial cells in manufacturing useful products), and molecular distillation should be encouraged. Jalani and colleagues [44] stressed that oil palm processors should embrace well integrated capital intensive, high volume and high extraction rate in their processing method in other to encourage high transformation of oil palm industry in the state and the entire country. An efficient processing technique increases the quality and quantity of food available for consumption and trade [42, 45-46]. Choosing one method of processing is by no means a simple one; it should be an informed decision, with a full recognition of all the factors at stake [47-49].

\section{Quality of Palm oil in Imo State}

Quality is a rapidly changing phenomenon. Issues bordering on the quality of palm oil should engage the attention of food scientists in Imo state so that palm oil produced in Imo is not classified as sub-standard. This will certainly have very wide implications and ramifications since the products which have palm oil as constituents are many and various. However, when talking about quality, there are indices that can portray if the palm oil is of good or poor quality. Examples of such indices are the physical, chemical and microbiological parameters. There are scantly studies available on the listed quality indicators for palm oil in Imo state. Microbiological analysis is an important index which could affect the physicochemical properties of palm oil [50-51]. Enyoh and coworkers [5] suggested that microorganisms present in palm oil constitute a major determinant of 
increased oil acidity. Microorganisms are minute living things classified as: bacteria, fungi, mold and unicellular algae [52]. They play several roles in human diet. In palm oil, these organisms play a fundamental role in the deterioration of dietary oil quality by increasing lipase activity. Patil [53] reported that $45 \%$ of existing lipases are produced by bacteria, $21 \%$ by fungi, $18 \%$ by animals, $11 \%$ by plants and $3 \%$ by algae. Tagoe [54] examined factors that influence palm oil quality, which revealed 15 fungi and 14 bacteria in palm oil. Okechalu and coworkers [55] also found 11 microorganisms on commercialized palm oil.

\section{Microorganisms commonly found in palm oil}

Majority of palm oil microbial species is part of normal flora which could have been introduced into the palm oil from the field and during processing especially by individuals under poor hygienic conditions [56-58]. The microorganisms that have been widely reported to be found in palm oil include Enterobacter, Bacillus, Proteus, Micrococcus, Staphylococcus, Aspergillus, Candida, Mucor and Penicillium species [53], Trichphyton schoenleinii and Microsporium canisas [59-60] and often cause diseases on ingestion of raw palm oil. Examples of such diseases include respiratory tract and urinary tract infections, aspergillosis, endophthalmitis, septicemia, meningitis, pulmonary osteomyelitis, endocarditis, myocarditis, candidiasis and mucormycosis respectively [61]. They can also degrade sweats to produce unpleasant odors; cause keratitis, otomycosis, bacteremia, genitourinary disease skin and soft tissue infections, gastrointestinal tract, bone and joint infections, endocarditis, central nervous infections, necrotizic enterocolitis and giving port of entry for septicemia and bacteremia. These microorganisms are opportunistic in nature are capable of affecting individuals that have suppressed immune system [53, 57-58].

\section{Dearth of Information on Microbial Qualities of Palm oil in Imo State}

Unfortunately, no study has been reported on microbial status of palm oil produced in Imo state. The little available studies regarding microbial species are on the palm oil mill effluent (POME) [62, 63] and palm oil extracts inhibitory abilities to microorganisms such as Staphylococcus aureus, Escherichia coli, Pseudomonas areuginosa, Candida albicans and Aspergillus niger [64]. Microbial load of palm oil from Imo State can be a call for concern.

\section{Physicochemical properties of palm oil in Imo State}

The only available data from literature on physicochemical quality of palm oil produced locally is compiled in table 1 . The $\mathrm{pH}$ ranges from 4.71 to 4.74 with average of 4.73 indicating that palm oil produced locally are acidic in line with high acidity. The high acidity is usually associated with locally produced palm oil. Acidity is an indicator of FFA content which indicates good harvest and good method of extraction when within standard range $[58,65]$. Their presence in palm oil also indicates the level of oil degradation during the extraction process, damaged fruits during harvesting as well as lipase activity, a reflector of oil quality impairment [8, 40, 54, 66, 67].

The palm oil produced locally in Imo state is highly degraded with high acid value and free fatty acid contents enhanced by the poor processing and storage technique (table 1.). Enyoh and coworker [5] observed increasing FFA content of palm oil produced locally in Okigwe, Imo state with different days under different stimulated storage conditions such as plastic and metal cans. It was reported that $70 \%$ of palm kernel oil produced locally in Imo state is stored in metal drums while $28 \%$ and $2 \%$ are stored in plastic container and glass bottles respectively [38]. These storage techniques are also very common for palm oil produced locally in Imo state. The average smoke point is $115^{\circ} \mathrm{C}$ which is not up to the range of $200-250^{\circ} \mathrm{C}$ set by the Nigerian Industrial Standard [68] suggesting that the palm oil may not be good for frying. 
Table 1. Physicochemical quality of palm oil produced in Imo state, Nigeria

\begin{tabular}{|c|c|c|c|c|c|c|c|}
\hline \multirow[t]{2}{*}{ Parameters } & \multicolumn{4}{|c|}{ Location } & \multirow[t]{2}{*}{ Range } & \multirow[t]{2}{*}{ Mean } & \multirow[t]{2}{*}{ Standards } \\
\hline & Okigwe & Ngor-kpala & Umuagwo & Mbaise & & & \\
\hline pH & $\begin{array}{l}4.74 \pm 0.01^{\mathrm{b}} @ 20^{\circ} \mathrm{C}, \\
4.74 \pm 0.01^{\mathrm{b}} @ 25^{\circ} \mathrm{C}, \\
4.73 \pm 0.00^{\mathrm{b}} @ 30^{\circ} \mathrm{C}, \\
4.71 \pm 0.01^{\mathrm{b}} @ 40^{\circ} \mathrm{C}, \\
4.71 \pm 0.01^{\mathrm{b}} @ 50^{\circ} \mathrm{C},\end{array}$ & N/A & $\mathrm{N} / \mathrm{A}$ & $\mathrm{N} / \mathrm{A}$ & $4.71-4.74$ & 4.73 & N/A \\
\hline $\begin{array}{l}\mathrm{AV}(\mathrm{mg} \\
\mathrm{KOH} / \mathrm{g})\end{array}$ & $29.88 \pm 1.39^{\mathrm{a}}$ & $20.76 \pm 1.18^{\mathrm{a}}$ & $24.97 \pm 1.19^{\mathrm{a}}$ & $37.59 \pm 6.36^{\mathrm{a}}$ & $20.76-37.59$ & 28.3 & $0.6^{\mathrm{c}}$ \\
\hline $\begin{array}{l}\text { FFA (mg } \\
\text { KOH/g) }\end{array}$ & $14.94 \pm 0.70^{\mathrm{a}}$ & $10.38 \pm 0.59^{\mathrm{a}}$ & $12.49 \pm 0.60^{\mathrm{a}}$ & $18.80 \pm 3.17^{\mathrm{a}}$ & $10.38-18.80$ & 14.153 & $3.5^{\mathrm{d}}$ \\
\hline $\begin{array}{l}\text { Smoke Point } \\
\left({ }^{\circ} \mathrm{C}\right)\end{array}$ & $114.2 \pm 0.00^{\mathrm{a}}$ & $116.20 \pm 0.00^{\mathrm{a}}$ & $115.6 \pm 0.00^{\mathrm{a}}$ & $114.00 \pm 0.00^{\mathrm{a}}$ & $114-116.2$ & 115 & $200-250^{\mathrm{c}}$ \\
\hline IV (wijj’s) & $2.84 \pm 0.00^{\mathrm{a}}$ & $0.48 \pm 0.14^{\mathrm{a}}$ & $2.50 \pm 0.06^{\mathrm{a}}$ & $0.89 \pm 0.03^{\mathrm{a}}$ & $0.48-2.84$ & 1.6775 & $45-53^{d}$ \\
\hline $\begin{array}{l}\mathrm{SV}(\mathrm{mg} \\
\mathrm{KOH} / \mathrm{g})\end{array}$ & $202.73 \pm 0.09^{\mathrm{a}}$ & $192.49 \pm 1.49^{\mathrm{a}}$ & $194.60 \pm 0.49^{\mathrm{a}}$ & $198.45 \pm 0.00^{\mathrm{a}}$ & $\begin{array}{l}192.49- \\
202.73 \\
\end{array}$ & 197.067 & $205^{d}$ \\
\hline EV & $172.86 \pm 1.49^{\mathrm{a}}$ & $171.74 \pm 2.67^{\mathrm{a}}$ & $169.63 \pm 0.49^{\mathrm{a}}$ & $160.86 \pm 6.35^{\mathrm{a}}$ & $\begin{array}{l}160.86- \\
172.85\end{array}$ & 168.773 & N/A \\
\hline MC (\%) & $\begin{array}{l}0.30 \pm 0.01^{\mathrm{a}}, \\
0.32 \pm 0.09^{\mathrm{b}}\end{array}$ & $0.33 \pm 0.11^{\mathrm{a}}$ & $0.86 \pm 0.94^{\mathrm{a}}$ & $0.26 \pm 0.06^{\mathrm{a}}$ & $0.30-0.86$ & 0.437 & $0.29^{d}$ \\
\hline $\begin{array}{l}\text { DENSITY } \\
(\mathrm{g} / \mathrm{ml})\end{array}$ & $0.91 \pm 0.00^{\mathrm{a}}$ & $0.87 \pm 0.00^{\mathrm{a}}$ & $0.91 \pm 0.00^{\mathrm{a}}$ & $0.88 \pm 0.00^{\mathrm{a}}$ & $0.87-0.91$ & 0.8913 & \\
\hline SG & $0.92 \pm 0.00^{\mathrm{a}}$ & $0.89 \pm 0.00^{\mathrm{a}}$ & $0.93 \pm 0.00^{\mathrm{a}}$ & $0.89 \pm 0.00^{\mathrm{a}}$ & $0.89-0.92$ & 0.9063 & $\begin{array}{l}0.898- \\
0.912^{d}\end{array}$ \\
\hline PV (mEq./Kg) & $16.50 \pm 0.42^{\mathrm{a}}$ & $24.80 \pm 0.85^{\mathrm{a}}$ & $15.60 \pm 0.57^{\mathrm{a}}$ & $14.10 \pm 0.14^{\mathrm{a}}$ & $14.10-24.80$ & 17.75 & $10^{\mathrm{d}}$ \\
\hline RI $\left({ }^{\circ} \mathbf{B x}\right)$ & $1.4615 \pm 0.00^{\mathrm{a}}$ & $1.4640 \pm 0.00^{\mathrm{a}}$ & $1.4635 \pm 0.00^{\mathrm{a}}$ & $1.4625 \pm 0.00^{\mathrm{a}}$ & $\begin{array}{l}1.4615- \\
1.4640\end{array}$ & 1.462 & N/A \\
\hline Viscocity & $\begin{array}{l}106.23 \pm 0.55^{\mathrm{b}} @ 20^{\circ} \mathrm{C} \\
77.48 \pm 0.53^{\mathrm{b}} @ 25^{\circ} \mathrm{C} \\
57.54 \pm 0.31^{\mathrm{b}} @ 30^{\circ} \mathrm{C} \\
35.54 \pm 0.15^{\mathrm{b}} @ 40^{\circ} \mathrm{C} \\
23.41 \pm 0.44^{\mathrm{b}} @ 50^{\circ} \mathrm{C}\end{array}$ & N/A & N/A & $\mathrm{N} / \mathrm{A}$ & $23.41-106.23$ & 60.04 & N/A \\
\hline
\end{tabular}

${ }^{\mathrm{a}-}[4],{ }^{\mathrm{b}-}[5],{ }^{\mathrm{c}}-[68],{ }^{\mathrm{d}}-[69]$.

*AV-Acid Value, FFA-Free Fatty Acids, IV-Iodine Value, SV-Saponification Value, EV-Ester Value, MC-Moisture Content, SG-Specific Gravity, PV-Peroxide Value, RI-Refractive Index

Enyoh and coworkers [4] recorded average iodine, saponification and ester values to be 1.6775 wijj's, $197.067 \mathrm{mg} / \mathrm{KOH}$ and $168.773 \mathrm{mg} / \mathrm{KOH}$ respectively for locally produced palm oil. The iodine value showed that palm oil produced in the area has low level of unsaturated fats. Saponification number is an indication of the amount of fatty saponifiable material in oil or fat. It gives information concerning the character of the fatty acids of the oil or fat and in particular regarding the solubility of their soaps in water [70]. The higher the saponification number of the oil, the more soluble the soap that can be made from it $[45,71]$. Moisture content reported for most palm oils in Imo State ranged from 0.30-0.86 \% higher than the $0.29 \%$ standard. High moisture enables microorganism activities in the palm oil causing palm oil impairment and thus high acidity. It has been pointed that high moisture could be due to the local producers not boiling the pure oil to reduce its moisture content $[72,73]$, probably because of the extract cost of energy. Peroxide values for oil produced locally are high suggesting high oxidation of the oil. Oxidized palm oil induces reproductive toxicity and organ toxicity particularly of the kidneys, lungs, liver and heart [14, 19, 74]. Therefore, palm oil with high peroxide value should be avoided. Other indicators such as viscocity, refractive index, specific gravity and density are in line with the NIS/SON standards, thus showing good physical properties.

\section{Conclusion}

It can be concluded that palm oil produced locally in Imo state is highly degraded and of poor quality. This is evident with average values of Acid, FFA, moisture and peroxide not conforming to NIS/SON standards for palm oil quality. This poor quality is probably due to the traditional methods of production and storage. Authors have concluded that mechanically processed palm oil 
has superior quality over traditionally processed ones. Without refining, palm oil produced locally in Imo state may be unsuitable for human consumption but might be good for other purposes such as in soap production. Also, there is a dearth of information/data available on quality of palm oil produced locally in Imo state especially on its microbial status. It is therefore recommended that food scientist should look in that direction to enhance proper understanding of the quality of palm oil produced locally. There should also be a public enlightenment in form of workshops and seminars through which the palm oil processors should be educated on the new methods for improving palm oil processing in the Imo state. Mechanized method of palm oil processing at every stage should be introduced to the processors to enable them boost up/or improve on their palm oil processing in the state.

\section{Conflict of Interest}

The authors declare that there is no conflict of interest.

\section{References}

[1] K. Poku, Origin of oil palm; small-scale palm oil processing in Africa. FAO Agricultural Services Bulletin 148. Food and Agriculture Organization, 2002.

[2] S.O. Aghalino, British colonial policies and the oil palm industry in the Niger Delta Region of Nigeria, 1900-1960, African Study Monographs. 21(1) (2000) 19-33.

[3] W.L. Siew, Palm oil, in: D.G. Frank (Ed), Vegetables Oils in Food Technology Composition, Properties and Uses. United Kingdom: Blackwell Publishing, 2002, pp. 59-97.

[4] E.C. Enyoh, C.E. Enyoh, C.E. Amaobi, Quality assessment of palm oil from different palm oil local factories in Imo State, Nigeria, World Scientific News. 88(2) (2017) 152-167.

[5] C.E. Enyoh et al., Physicochemical properties of palm oil and soil from Ihube community, Okigwe, Imo State, Nigeria, International Letters of Natural Science. 62 (2017) 35-49.

[6] W.L. Siew, Chemical and physical characteristics of palm oil and palm kernel oils and their crystalisation behavior, in: M.S. Zainon, M. Johari (Eds.), Lectures on Palm Oil and Its Uses. MPOB, Bangi, 2002, pp. 64-85.

[7] SoyStats (2016), World vegetable oil consumption 2015. Available: http://www.soystats.com/wp-content/uploads/SoyStats_2016.pdf. Accessed: 12/06/2018.

[8] VA. Aletor, G.A. Ikhena, V. Egharevba, The quality of some locally processed Nigerian palm oil: An estimation of some critical variables, Food Chemistry. 36 (1990) 311-317.

[9] P. Akubor, G.I. Ogu, Quality attributes of fresh palm oil produced from selected communities around Anyigba, Kogi State, Nigeria. Nigerian Journal of Nutritional Sciences. 33(1) (2012) 12-17.

[10] K. Sundram, R. Sambanthamurthi, Y.A. Tan, Palm fruit chemistry and nutrition, Asia Pacific J. Clin. Nutr. 12(3) (2003) 355-362.

[11] R. Sambanthamurthi, K. Sundram, Y. Tan, Chemistry and biochemistry of palm oil, Prog. Lipid Res. 39 (2000) 507-558.

[12] A. Mancini et al., Biological and nutritional properties of palm oil and palmitic acid: effects on health, Molecules. 20(9) (2015) 17339-17361.

[13] R.H.V. Corley, P.B.H. Tinker, The oil palm, John Wiley and Sons, 2008.

[14] O.B. Imoisi et al., Palm oil, its nutritional and health implications, J. Appl. Sci. Environ. Manage. 19(1) (2015) 127-133.

[15] N. Chandrasekharan, K. Sundram, Y. Basiron, Changing nutritional and health perspectives on palm oil, Brunei International Medical Journal. 2 (2000) 417-427. 
[16] K.G. Berger, Food uses of palm oil. Kuala Lumpur, Bulletin Perkebunan. 22 (1992) 230-238.

[17] S.A. Kheiri, End uses of palm oil: Human Food. In Critical Reports on Applied Chemistry, Vol. 15, Palm oil ed. F.D. Gunstone, London, 1987, pp. 71-83.

[18] H.M. Roche, Low-fat diets, triglycerides and coronary heart disease risk, Nutrition Bulletin. 25 (2000) 49-53.

[19] M. Sutapa, M. Analava, Health effects of palm oil, J. Hum. Ecol. 26(3) (2009) 197-203.

[20] M. Stuchlik, S. Zak, Vegetable lipids as components of functional foods, Biomedical Papers of the Medical Faculty of the University Palacky, Olomouc, Czechoslovakia. 146(2) (2002) 3-10.

[21] C. Rona, F. Vailati, E. Berardesca, Cosmetic treatment of wrinkles, Journal of Cosmetic Dermatology. 3(1) (2004) 26-34.

[22] U.R. Nagendran, Y.M. Unnithan, K.S. Choo, Characteristics of red palm oil, a carotene-and vitamin E-rich refined oil for food uses, Food and Nutrition Bulletin. 21(2) (2000) 77-82.

[23] L.O.E. Nwauwa, Palm oil marketing and distribution pattern in Imo state, Nigeria: An application of linear programming model. E3 Journal of Agricultural Research and Development. 2(1) (2012) 037-043

[24] G.T. Amangabara, Drainage Morphology of Imo Basin in Anambra-Imo River Basin Area, of Imo State, Southern Nigeria. Journal of Geography, Environment and Earth Science International. 3(1) (2015) 1-11.

[25] Imo State Government (2010). About Imo State, Nigeria. Available: http://www.imostate.gov.ng/info/AboutImo. Retrieved: 10 June 2018

[26] Vanguard Nigeria (2015), Exploring the resource control option - Imo State, by Futureview CEO, Elizabeth Ebi. Available: vanguardngr.com. Retrieved: 10/06/2018.

[27] Food and Agriculture Organization (FAO) (2012). Trade data base, Production data base http://faostat.fao.org/. Accessed 10/06/2018.

[28] FAOSTAT (2017) FAO Crops Statistics Database. Available: http://faostat3.fao.org/browse/Q/QC/E. Accessed: 12 June 2018.

[29] H. Gourichon, Analysis of incentives and disincentives for Palm Oil in Nigeria. Technical notes series, MAFAP, FAO, Rome, 2013.

[30] IFPRI (2010). A 2006 Social Accounting Matrix for Nigeria, Methodology and Results.

[31] Foundation for partnership in the Niger Delta (PIND) (2011). Palm Oil Value Chain Analysis in the Niger Delta.

[32] U. Omoti, Oil palm sector analysis in Nigeria. Main Report, Submitted to the United Nations Industrial Development Organization (UNIDO), Abuja. 64(18) (2009) 275.

[33] NIFOR, Nigerian Institute for oil research, 2012. Available: www.nifor.org. Accessed: $14 / 06 / 2018$.

[34] F. Olagunju, Economics of palm oil processing in Southwestern Nigeria, International Journal of Agricultural Economics and Rural Development. 4(8) (2008) 125-133.

[35] P.O. Agbaire, Quality assessment of palm oil sold in some major markets in Delta State, southern Nigeria, African Journal of Food Science and Technology. 3(9) (2012) 223-226.

[36] E.A. Kelechi et al., Evaluating oil palm fresh fruit bunch processing in Nigeria, Waste Management \& Research. 36(3) (2018) 236-246.

[37] E.A. Udensi, F.C. Iroegbu, Quality assessment of palm oil sold in Major markets in Abia State, Nigeria, Agro-Science. 6(2) (2007) 25-27. 
[38] O.C. Okeke, C.G. Oluka, Review of Palm kernel oil processing and storage techniques in South East Nigeria, Journal of Experimental Research. 5(1) (2017) 1-7.

[39] Agro Nigeria (2018). Available: https://agronigeria.com.ng/oil-palm-imo-community-getsn90m-processing-factory/. Accessed: 18/06/2018.

[40] D.O. Ataga, C.O. Ilechie, U. Omoti, Small-scale palm oil processing technology in Nigeria. Seminar paper presented to BUROTROP-AFOPDA on Small and Medium Scale Palm and Coconut Technologies, Accra, Ghana, 1993.

[41] Food and Agriculture Organization (FAO) (2004). Small-scale palm oil processing in Africa. FAO Agricultural Services Bulletin 148.

[42] U.J. Etoamaihe, K.C. Ndubueze, Development of motorized African breadfruit dehuller, Journal of Engineering and Applied Science. 5 (2010) 312-315.

[43] H.U. Nwalieji, H.U. Ojike, Characteristics of small-scale palm oil production enterprise in Anambra State, Journal of Agricultural Extension. 22(1) (2018) 1-13.

[44] B.S. Jalani, D. Ariffion, K.W. Chan, Malaysia's contribution to improving the value and use of palm oil through moderm technologies in Burotrop Bulletin. 19 (2003) 25.

[45] S.A. Alyas, A. Abdulah, N.A. Idris, Changes of betacarotene content during heating of red palm olein, J. Oil Palm Res. (2006) 99-102.

[46] Onwuka G I and Akaerue B I (2006). Evaluation of the quality of palm oil produced by different methods of processing. Research Journal of Biological Sciences. 1 (1-4): 16-19

[47] F.M. Ugwu, M. Odo, O. Osborne, The quality of locally processed palm oil from Ebonyi and Enugu States, in: C.N. Ubbaonu, S.O. Eke, A. Uzoma (Eds.), Proceedings of the 26th annual NIFEST conference, 4th -8th November, 2002, Owerri, 2002, pp. 47-48.

[48] M.U. Dimelu, V. Anyaiwe, Priorities of smallholder oil palm producers in Ika Local Government Area of Delta State: implication for agricultural extension service in Nigeria, World Journal of Agricultural Sciences. 7(2) (2011) 117-123.

[49] C.J. Vincent, R. Shamsudin, A.S. Baharuddin, Pre-treatment of oil palm fruits: A review, Journal of Food Engineering. 143 (2014) 123-131.

[50] J. Zhou, The role of microorganisms in deterioration of vegetable oil and measures of controlling, Proceedings of the 7th International Working Conference on Stored-product Protection - 1, 1999, pp. 288-292.

[51] I.L. Pepper, C.P. Gerba, Environmental microbiology. A laboratory manual, Second edition. Elsevier Academic Press, 2005.

[52] B.C. Likeng-Li-Ngue et al., Genetic determinism of oil acidity among some DELI oil palm (Elaeis guineensis Jacq.) progenies, Afr. J. Biotechnol. 15(34) (2016) 1841-1845.

[53] K.J. Patil, Z.C. Manojkumar, T.M. Raghunath, Lipase biodiversity, Indian J. Sci. Technol. 4(8) (2011) 971-982.

[54] S.M. Tagoe, M.J. Dickinson, M.M. Apetorgbor, Factors influencing quality of palm oil produced at the cottage industry level in Ghana, International Food Research Journal. 19(1) (2012) $271-278$.

[55] J.N. Okechalu et al., Microbiological quality and chemical characteristics of palm oil sold within Jos Metropolis, Plateau State, Nigeria, Journal of Microbiology and Biotechnology Research. 1(2) (2011) 107-112. 
[56] E.I. Ohimain et al., Assessment of the quality of crude palm oil produced by smallholder processors in Rivers State, Nigeria, Nigerian Journal of Agriculture, Food and Environment. 8(2) (2012) 28-34.

[57] S.C. Izah, A.A. Oduah, E.I. Ohimain, Effects of temperature and fermentation period on the recovery of second grade palm oil from palm press fiber, International Journal of Engineering Science and Innovative Technology. 3(5) (2014) 131-138.

[58] E.G.F Ngando et al., Assessment of the quality of crude palm oil from smallholders in Cameroon, Journal of Stored Products and Postharvest Research. 2(3) (2011) 52-58.

[59] S.C. Izah, E.I. Ohimain, Microbiological quality of crude palm oil produced by smallholder processors in the Niger Delta, Nigeria, Journal of Microbiology and Biotechnology Research. 3(2) (2013) 30-36.

[60] S.C. Enemuor et al., Environmental and fungal contamination of palm oil sold in Anyigba Market, Nigeria, African Journal of Microbiology Research. 6(11) (2012) 2744-2747.

[61] E.I. Ohimain, S.C. Izah, A.D. Fawari, Quality assessment of crude palm oil produced by semimechanized processor in Bayelsa state, Nigeria, Discourse Journal of Agriculture and Food Sciences. 1 (11) (2013) 34-46.

[62] A.W. Verla, P. Adowei, E.N. Verla, Physicochemical and microbiological characteristic of palm oil mill effluent (Pome) in Nguru: Aboh Mbaise, Eastern Nigeria, Acta Chim. Pharm. Indica. 4(3) (2014) 119-125.

[63] I.J. Ibe et al., Effects of Palm Oil Mill effluent (Pome) on soil bacteria and enzymes at different seasons, International Journal of Current Microbiology and Applied Sciences. 3(10) (2014) 928934.

[64] U.N. Ekwenye, C.A. Ijeomah, Antimicrobial Effects of Palm Kernel Oil And Palm Oil, KMITL Sci. J. 5(2) (2005) 11-19.

[65] M.F. Olorunfemi et al., Quality assessment of palm oil on sale in major markets of Ibadan, Nigeria, International Journal of Food Research. 1 (2014) 8-15.

[66] E.G.F. Ngando et al., Assaying lipase activity from oil palm fruit (Elaeis guineensis) mesocarp, Plant Physiol. Biochem. 444 (2006) 611-617.

[67] D.T. De Almeida et al., A quality assessment of crude palm oil marketed in Bahia, Brazil, Grasas y Aceites. 64(4) (2013) 387-394.

[68] NIS, Nigerian Industrial Standards, Standard for Edible Vegetable oil, 1992.

[69] SON (2000), Standard Organization of Nigeria. Standards for Edible Refined Palm Oil and Processed from PP.2- 5

[70] S.A. Odunfa, Bacteria involved in the deterioration of Nigerian palm oil under storage, International Bioderioration Bulletin. 25 (1989) 393-405.

[71] F.F. Akinola et al., Physicochemical properties of palm oil from different palm local factories in Nigeria, Journal Food, Agriculture and Environment. 8 (2010) 264-269.

[72] M.U. Orji, T.I. Mbata, Effect of extraction methods on the quality and spoilage of Nigerian palm oil, African Journal of Biochemistry Research. 2(9) (2008) 192-196.

[73] C.H. Tan et al., Extraction and physicochemical properties of low free fatty acid crude palm oil, Food Chemistry. 113 (2009) 645-650.

[74] O.D. Ekpa, R.U.B. Ebana, Comparative Studies of Mmanyanga, Palm and Coconut Oils; Antimicrobial Effects of the Oils and their Metallic Soaps on Some Bacteria and Fungi, Global Journal of Pure and Applied Sciences. 1(2) (1996) 155-163. 